\title{
Aleuria bicucullata versus Aleuria luteonitens (Pezizales, Ascomycetes)
}

\author{
PETER BILLEKENS
}

\begin{abstract}
BILLEKENS, P. 1994: Aleuria bicucullata versus Aleuria luteonitens (Pezizales, Ascomycetes). - Karstenia 34:35-41. Helsinki. ISSN 0453-3402

On the basis of fresh material collected in the environs of Venlo (province of Limburg, The Netherlands), the author describes two species of the genus Aleuria which are extremely difficult to distinguish in the field. Microscopical studies proved this material to belong to Aleuria bicucullata (Boud.) Gillet and A. luteonitens (Berk. \& Broome) Gillet. In the present paper these taxa are compared and contrasted in detail, with Table 1 listing the differences between them.
\end{abstract}

Key words: Aleuria bicucullata, Aleuria luteonitens, anatomical differences, Ascomycetes, Ascomycotina, Pezizales

Peter Billekens, Lodewijk van Nassaustraat 7, NL-5923 BC Venlo, The Netherlands

\section{Introduction}

It may safely be assumed that most mycologists are familiar with the widespread ascomycete Aleuria aurantia Pers., type species of the genus Aleuria. In 1988, the author (Billekens 1990) received a collection of a taxon closely related to this species. The specimens I examined from this collection were identified as (following Boudier 1905-1910; compare plates 317a-e and 318a-e) intermediate in habit, with young cup-shaped apothecia representing $A$. bicucullata (plate 318 ), and adult specimens being typical A. luteonitens, growing in dense groups, with in the centre a plicate-veined hymenium and an undulate margin (plates 317a and c). On the basis of an anatomical study I was able to identify the species as Aleuria bicucullata (Boud.) Gillet.

\section{Aleuria bicucullata (Boud.) Gillet - Fig. 1}

Champ. Fr. Disc.: 206. 1886. — Peziza bicucullata Boud., Bull. Soc. Bot. France 28: 93. 1881. - Humaria bicucullata (Boud.) Quél., Ench. Fung.: 288. 1886.

Apothecia sessile, in dense groups, $1.5-10 \mathrm{~mm}$ in diameter, 0.6-1.5 mm high, gymnohymenial.
Receptacle at first subspherical or reversed conical; later flat, cup-shaped, convex or irregular; obliquely flattened; with rounded, never torn, undulate margin (with age), pruinose, maize yellow (Methuen, 4A6, see Kornerup \& Wanscher, 1978), buttercup yellow (Methuen, 4A5), brownish red (Methuen, 8C6). Hymenium in adult individuals (through torsion of abutting apothecia) in the centre plicate-veined, bright golden yellow (Methuen, 5B7), brownish yellow (Methuen, 5C8), reddish golden (Methuen, 6C7), brownish orange (Methuen, 6C8). Hypothecium 10-20 $\mu \mathrm{m}$ thick, hyphae parallel to asci, septate; cells small, more uniformly ovoid, reniform, oval, weakly cyanophilous, 7-20 × 6-9.3 $\mu \mathrm{m}$ (textura prismatica to textura angularis). Medullary excipulum 70-80 $\mu \mathrm{m}$ thick, well demarcated from ectal excipulum, many hyphae grading into paraphyses towards the rim, at right angles to parallel to apothecium, branching, septate; cells short to elongate, regularly or irregularly ventricose, reniform, turbinate, lobate, near-circular, weakly cyanophilous, 9-40 × 2.5-14 $\mu \mathrm{m}$ (textura intricata). Ectal excipulum 70-110 $\mu \mathrm{m}$ thick, margin not projecting over hymenium, excipulum here $17-25 \mu \mathrm{m}$ thick; hyphae at right angles to apothecium, branching, septate; 


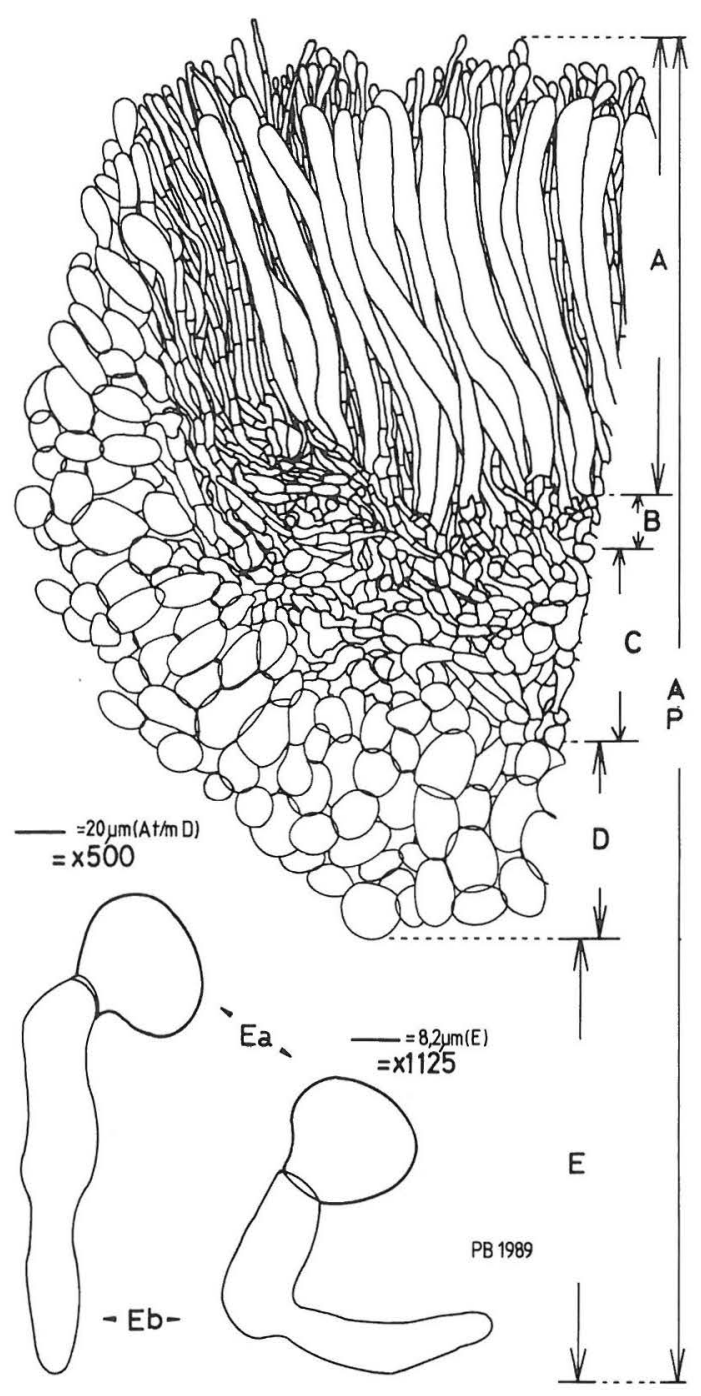

Fig. 1A-E. Aleuria bicucullata. Median section of margin of apothecium. - A) hymenium, B) hypothecium, C) medullary excipulum, D) ectal excipulum. Ea: endcells ectal excipulum, Eb: hyphoid hairs.

cyanophilous, short to elongate globose, ovoid, pyriform, angular to irregularly angular to nearcircular, isodiametric, 19-26 × 7-12 $\mu \mathrm{m}$ (textura globulosa to textura angularis), with excipular hairs. Hairs $8-15 \mu \mathrm{m}$ in diameter, hyaline, hyphoid, straight or sinuous, round at the tops, thin walled, septate, outstanding. Spores ellipsoid; hyaline with yellowish, strongly cyanophilous ornament; uninucleate, uniseriate; with 1 or 2 large oil globules, either with or without a single or a few smaller ones, smooth; with ornament consisting of a combination of uninterrupted 5.5-6.3 $\mu \mathrm{m}$ high ribs which thus form socalled collars or caps, and of irregularly interrupted 2.8-6.3 $\mu \mathrm{m}$ high ribs and a fine network of low ribs interconnecting the high ribs; $13.1-14.8$ $\times 7.4-8.2 \mu \mathrm{m}$ without, $17.6-22.1 \times 9.0-11.1 \mu \mathrm{m}$ with ornament. Asci non-amyloid, 8-spored, uniseriate, operculate, cylindrical, gradually narrowing towards pleurorhynchous base, 183-214 $\times 10-15 \mu \mathrm{m}$. Paraphyses in hymenium mostly projecting above asci, straight, branching; in lower part 2.3-3.3 $\mu \mathrm{m}$, towards the top becoming gradually broader to clavate or irregularly widened, 4.4-8.2 $\mu \mathrm{m}$; septate; with orange, intracellular, carotenoid pigment.

Habitat and distribution. Observed on gravelly, calcareous, humus-deficient sand (also on/in organic material lying on the surface) or in symbiosis [?] with Molinia caerulea; amongst Ceratodon purpureus, Calluna vulgaris, at the foot of burnt-down clumps of $M$. caerulea; occurring in large numbers; in rainy periods; rather rare. France (Boudier 1881, 1905-1910; Patouillard 1885; Quélet 1886; Grélet 1938; Le Gal 1947); United States (Seaver 1928, 1942); Denmark (Dissing 1983); Germany ? (Moser 1963); Russia, Norway, Czech Republic (Kristiansen 1985) and The Netherlands (Billekens 1990).

Specimen examined

The Netherlands. Limburg: Venlo, Grote Heide, 12.X.1988 Gatzen (Herb. Billekens, L), 15.X.1988 Billekens (Herb. Billekens).

In December 1992, I came across a number of ascomycetes which closely resembled Aleuria bicucullata in a field levelled with loam and sand, bordering on a small clay pit. Young individuals were wholly identical with $A$. luteonitens (see Boudier, 1905-1910; plate 317). However, what I missed in this comparatively large group was the dense mode of growth and the plicate-veined hymenium, features which Boudier illustrated for this species in his plates $317 \mathrm{a}$ and c. Upon an anatomical examination, making use of Berkeley \& Broome (1871), Boudier (1905-1910) and Grelet (1938), I was able to confirm that the material is Aleuria luteonitens. 


\section{Aleuria luteonitens (Berk. \& Broome) Gillet - Figs. 2, 3}

Champ. Fr. Disc.: 205. 1886, as 'luteo-nitens'. - Peziza luteonitens Berk. \& Broome, Ann. Mag. Nat. Hist., ser. 4, 7: 425.1871.

?Peziza luteonitens var. josserandii Grélet, Bull. Soc. Bot. Centre-Ouest: 72. 1938.

?Octospora pleurozii Eckblad, Nytt Mag. Bot. 15: 47. 1968.

Apothecia sessile, in a single group, 7-10 mm in diameter, 2-3 mm high, gymnohymenial. Receptacle at first turbinate, then cup-shaped, obliquely cup-shaped; with broad, never torn, rounded, very finely serrate margin; pubescent; at first cream (Methuen, 4A3), pale yellow (Methuen, 3A3), light yellow (Methuen, 4A4); later in lower half remaining thus, towards the margin adopting the colour of the hymenium. Hymenium smooth; at first flat, later concave; bright buttercup yellow (Methuen, 4A7), deep yellow/reddish yellow (Methuen, 4A8), melon yellow (Methuen, 5A6). Hypothecium 40-60 $\mu \mathrm{m}$ thick, well demarcated from medullary excipulum; hyphae mostly at right angles to medullary excipulum, branching, septate; cells relatively large, short to elongate urn-shaped, pyriform, ventricose, reniform, turbinate, lobate, irregular, weakly cyanophilous, $6-28 \times 4-12 \mu \mathrm{m}$ (textura epidermoidea to textura intricata). $\mathrm{Me}$ dullary excipulum in lower part of apothecium 80-110 $\mu \mathrm{m}$ thick; easily distinguished from ectal excipulum, with which it gradually coalesces halfway to the margin; hyphae mostly parallel to apothecium, branching, septate; cells short to long, turbinate, ventricose, utriform, reniform, irregular, hyaline, weakly cyanophilous, 7-31 x 2-13 $\mu \mathrm{m}$ (textura porrecta). Ectal excipulum in lower part of apothecium to halfway margin 80$125 \mu \mathrm{m}$ thick, hyphae at right angles to that of medullary excipulum, branching, septate; from there to below the broadly rounded margin which does not project above the hymenium, inclusive of medullary excipulum, 40-105 $\mu \mathrm{m}$ broad, hyphae parallel or at right angles to apothecium, branching, septate; cells weakly cyanophilous, short to elongate-angular, almost pyriform, lobate, isodiametric, 10-53 x 11-28 $\mu$ m (textura globulosa to textura angularis), with excipular hairs. Hairs $6.2-17.3 \mu \mathrm{m}$ in diameter, hyaline, hyphoid, straight or sinuous, with rounded tops, very thin walled, septate, often appressed or

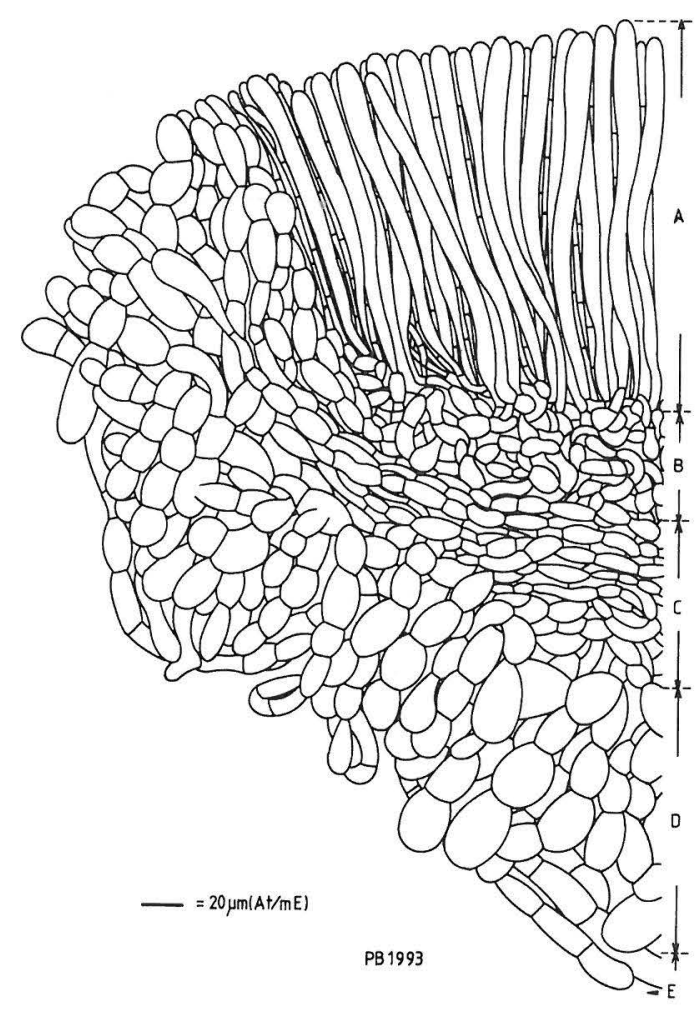

Fig. 2A-E. Aleuria luteonitens. Median section of margin of apothecium. - A) hymenium, B) hypothecium, C) medullary excipulum, D) ectal excipulum, E) hyphoid hairs.

outstanding. Spores ellipsoid, hyaline; with yellowish cyanophilous ornament, uninucleate, uniseriate, with two moderately large oil globules, smooth; ornamented with a complete or incomplete network of angular to irregular meshes which at their poles may be stretched out to apiculi, separated by $0.5-2.3 \mu \mathrm{m}$ high, very thin to moderately broad ribs; in places where ribs are interrupted the remains form pointed, wart-like protuberances; $13.9-16.1 \times 5.9-8.6 \mu \mathrm{m}$ without, $16.4-22.9 \times 8.1-10.3 \mu \mathrm{m}$ with ornament. Asci non-amyloid, uniseriate, operculate, cylindrical or subcylindrical, remaining equally wide or slightly narrowing to pleurorhynchous base, projecting above paraphyses in hymenium, 80-210 × 8-11 $\mu \mathrm{m}$. Paraphyses straight or slightly curved, in lower half branching; in lower part $1.2-3.3 \mu \mathrm{m}$, gradually broadening towards 

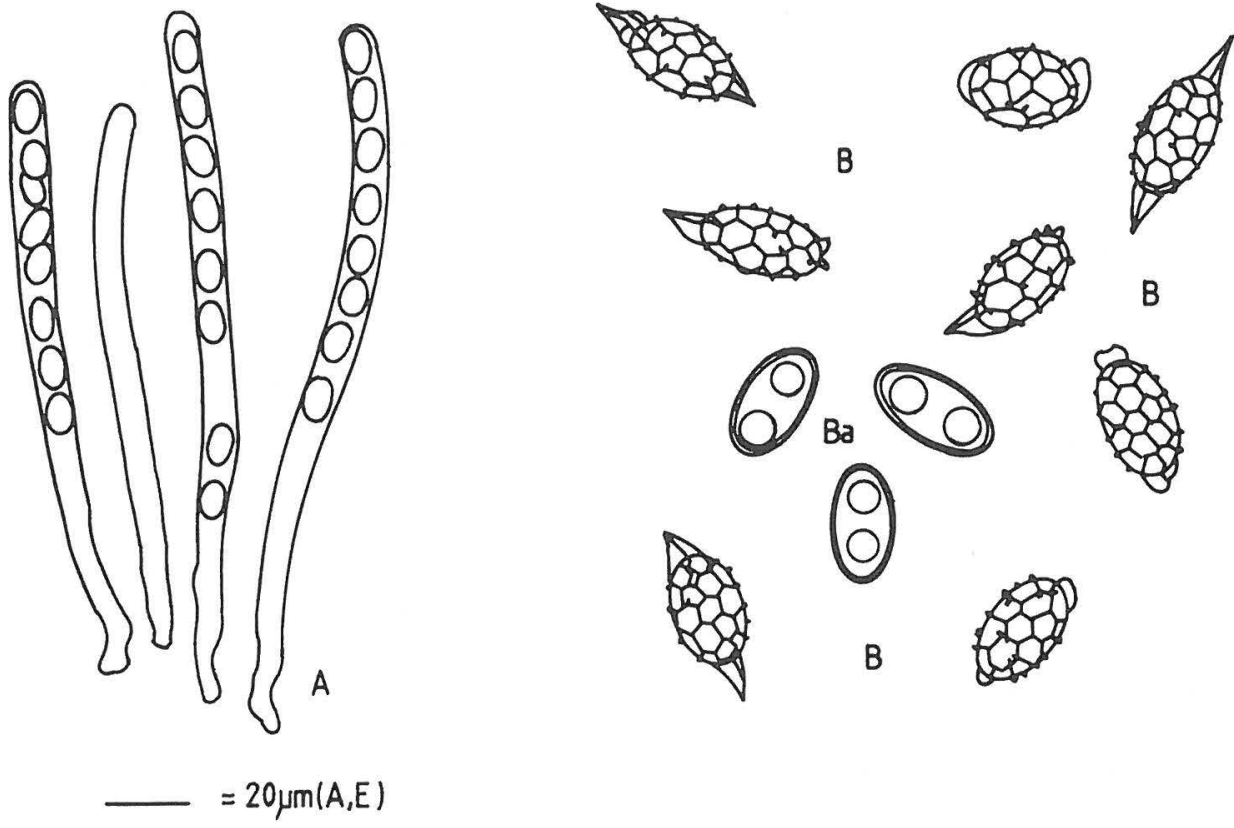

B

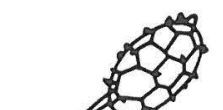
B<smiles>Brc1ccccc1</smiles><smiles>c1ccc2ccccc2c1</smiles>

(O)

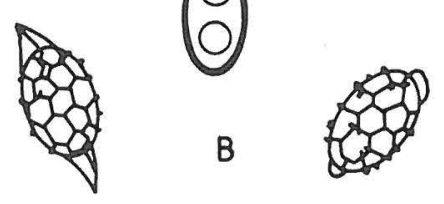

PB 1993
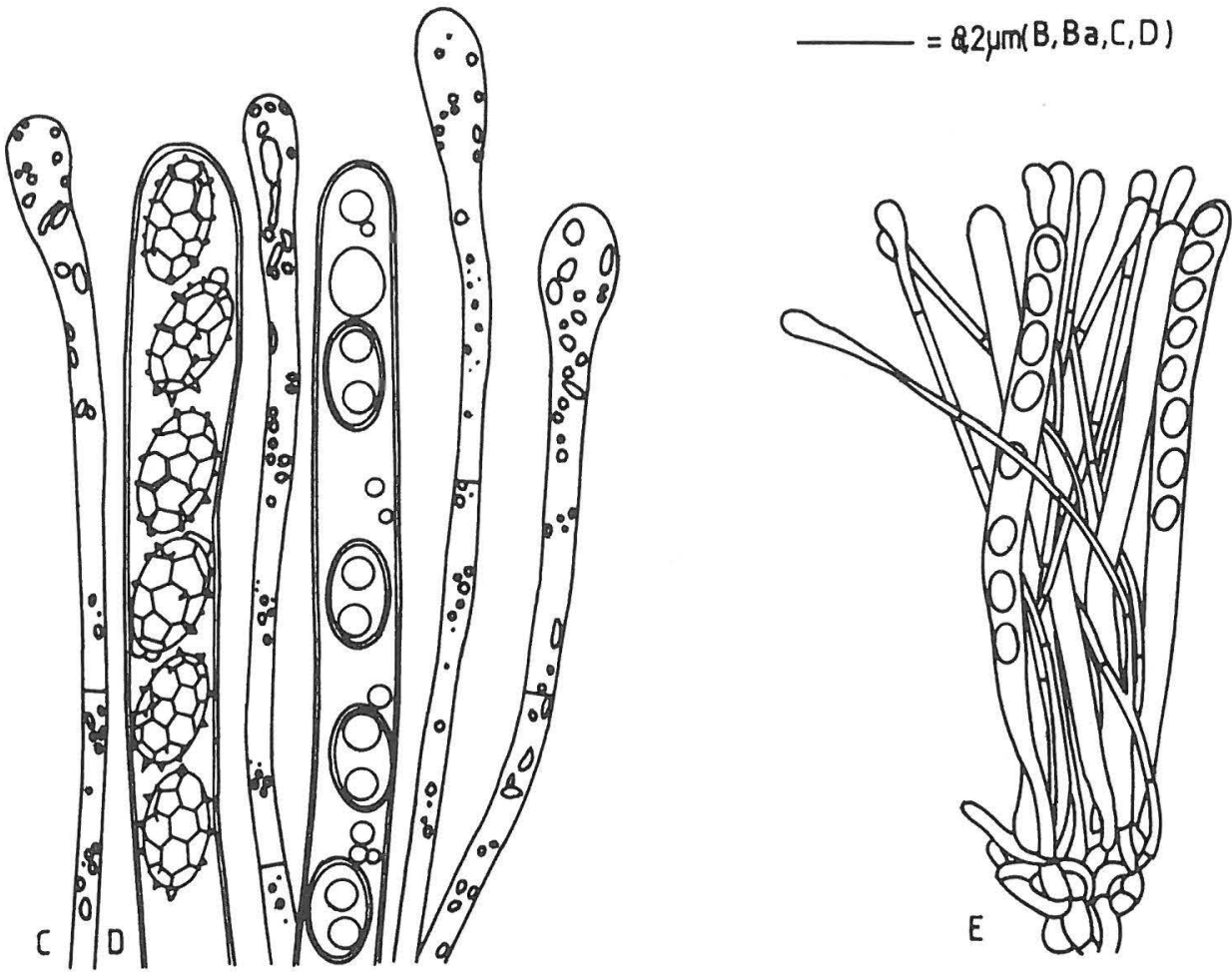

Fig. 3A-E. Aleuria luteonitens. - A) asci with (one without) contents, B) mature spores (without contents); Ba half mature spores, C) upper parts of paraphyses with intracellular carotenoid pigment, D) parts of closed asci with contents, E) asci and paraphyses with transition into hypothecium. 
top or clavate or irregularly widened there, 4.9$9.8 \mu \mathrm{m}$, septate, with intracellular, carotenoid pigment.

Habitat and distribution. Observed in a field levelled with loam and sand bordering on a disused clay pit; no trees in direct vicinity; amongst Ceratodon purpureus; in a single large group; rather rare. Great Britain (Berkeley \& Broome 1871; Cooke 1875-1879; Dennis 1978), France (Gillet 1886; Boudier 1905-1910; Grélet 1938), Germany (Moser 1963).

Specimen examined

Germany. Nordrhein-Westfalen: Kaldenkirchen, Ravens heide, 21.XII.1992 Billekens (Herb. Billekens).

As indicated above, following a comparison of macroscopical features with literature data, it became clear that external features may vary to such an extent that identification in the field is almost impossible. I also noted that these species could be distinguished on details of their anatomy. Both taxa are described in more detail below, based on the results of my studies.

\section{Discussion}

\section{Spore ornamentation}

According to Boudier (1881; 1905-1910: 177), Aleuria (Peziza) bicucullata is especially characterised by spores that possess fine spinelets as well as a few larger spines and nearly always also caps, so well illustrated in the Icones (plate $318 \mathrm{k}$ ). He described and illustrated these spores by means of regular light microscopy. This is apparent from the illustration, the scale of which is given as $820: 1$. The same spore ornament was also observed by Grélet (1938) and Le Gal (1947). Le Gal devoted a separate paper to the evolution of this spore ornament in Aleuria bicucullata. In those days, technically speaking, mycologists were handicapped, not having access to such methods as scanning electron microscopy. Today, SE microscopy is widely used in mycology, especially in the study of spore ornaments, ultrastructures and opening mechanisms in Ascomycetes (see Merkus 1973, 1974, 1975, 1976; Van Brummelen 1981; Verkley 1992). Thus Dissing (1983) and Kristiansen (1985) discovered with the help of Schumacher and SEM facilities that what Boudier had noted in $A$. bicucullata and illustrated as 'épines' and 'collerettes', in fact would be better described as, 'being part of ribs c.q. forming a reticular mesh over the spores' (see Billekens 1990).

In contrast, in Aleuria luteonitens, isolated spinelets are found on the spores (see Berkeley \& Broome 1871), as illustrated by Boudier (19051910 ) in the Icones (plate $317 \mathrm{j}$ ), who described the ornament of this species on page 176 as 'verrues pointues'. Unfortunately, this is again an erroneous interpretation. A few decades later, Grélet (1938) reached the same conclusion when re-examining the material depicted in the Icones. $\mathrm{He}$ characterised the ornament as: 'verrues pointues....en...réalité, étant aspérulées par le crêtes proéminentes d'un reseau mal forme.' He illustrated this in figure 6 , on page 72 . Le Gal (1947), upon having examined material of $A$. luteonitens preserved in Boudier's herbarium as well, came to the same conclusion and demonstrated this in text-figure 48F, on page 198 .

The ornament of specimens of A. luteonitens I examined (Fig. 3B) displays a strong resemblance to that of Sowerbyella reguisii (Quél.) J. Moravec (Moravec 1985: 429-430, figs. 1, 6, 7; Moravec 1986: 98). Species of the genus Sowerbyella, however, are characterised by a different tissue type (see Boudier 1905-1910: plate 335; Nannfeldt 1938; Heim 1962).

A comparison of the spore ornaments of the above-mentioned species shows that $A$. bicucullata has a comparatively large, to $6.3 \mu \mathrm{m}$ high, regular to irregular ribwork (see Billekens 1990, fig. 2e), while A. luteonitens is characterised by a fine web-like ornament which reaches heights of $2.3 \mu \mathrm{m}$ or less (see Fig. 3B).

\section{Hypothecium and excipulum}

In principle, light microscopy may have as many advantages as does SEM, especially so in the examination of excipular/hypothecium structures (see Figs 1,2). This is apparent from Boudier's illustrations of hypothecium structures in the Icones. From plate $317 \mathrm{f}$ it is clear that $A$. luteonitens has a different kind of hypothecium (i.e. larger, differently shaped cells) than does $A$. bicucullata (plate 318f). I examined the hypothecia of both species and the cells indeed differ in size, form and position. In A. luteonitens the comparatively large, differently sized cells are found in a textura epidermoidea/intricata tissue, while the small, more uniformly sized cells 
of A. bicucullata are found in a transitional tissue (textura prismatica/angularis). The hypothecium layers also vary in thickness: in the former species this is $40-60 \mu \mathrm{m}$ thick, in the latter 10$20 \mu \mathrm{m}$. In addition, I studied in more detail the medullary excipulum of both species: $A$. bicucullata has a textura intricata type tissue, $A$. luteonitens a different kind of tissue (textura porrecta). About the medullary excipulum the following can be stated: cells vary considerably in size. In $A$. luteonitens the cells of the medullary excipulum are much larger than those in $A$. bicucullata $(10-53 \times 11-28 \mu \mathrm{m}$ versus $19-26 \times 7-$ $12 \mu \mathrm{m})$.

\section{Hairs}

Both species of Aleuria have 'hyphoid' hairs, i.e. they resemble hyphae. In Aleuria bicucullata the hairs are predominantly outstanding: Boudier illustrated this feature in plate $318 \mathrm{~b}$ : a hairy structure, depicted in a more or less fictitious manner; the outstanding hairs are especially well illustrated in Kristiansen's (1985) figure 22e on page 429. In Aleuria luteonitens the hairs are appressed to the outermost cells of the ectal excipulum, as seen in Boudier's illustration (figures $317 \mathrm{k}$ ) and my own drawing of this structure (Fig. 2).

\section{Summary}

The aim of the present paper was to point out that Aleuria bicucullata and Aleuria luteonitens are difficult to distinguish in the field, and that differences are found especially in their anatomy. From Table 1 it is clear that the spore ornaments and tissues of the above-mentioned species differ

Table 1. Combination of microscopical differences between Aleuria bicucullata and A. luteonitens.

\begin{tabular}{|c|c|c|}
\hline & A. bicucullata & A. luteonitens \\
\hline Hairs & outstanding & appressed, outstanding \\
\hline $\begin{array}{l}\text { Ectal excipulum } \\
\text { demarcated } \\
\text { towards margin } \\
\text { cell size } \\
\text { thickness of margin }\end{array}$ & $\begin{array}{l}\text { invariably good } \\
\text { 19-26 } \times 7-12 \mu \mathrm{m} \\
\text { narrow, } 17-25 \mu \mathrm{m}\end{array}$ & $\begin{array}{l}\text { good tohalfway margin } \\
\text { than difficult } \\
10-53 \times 11-28 \mu \mathrm{m} \\
\text { narrow to relatively wide, } \\
40-105 \mu \mathrm{m} \text { inclusive of Med } \\
\text { ex. }\end{array}$ \\
\hline $\begin{array}{l}\text { Medullary excipulum } \\
\text { tissue type }\end{array}$ & textura intricata & textura porrecta \\
\hline $\begin{array}{l}\text { Hypothecium } \\
\text { thickness } \\
\text { tissue type } \\
\text { angularis }\end{array}$ & $\begin{array}{l}10-20 \mu \mathrm{m} \\
\text { textura prismatica to textura }\end{array}$ & $\begin{array}{l}40-60 \mu \mathrm{m} \\
\text { textura epidermoidea to } \\
\text { textura intricata }\end{array}$ \\
\hline $\begin{array}{l}\text { Spore ornament } \\
\text { height/structure }\end{array}$ & $\begin{array}{l}2.8-6.3 \mu \mathrm{m} \text {, relatively large, } \\
\text { lattice }\end{array}$ & $0.5-2.3 \mu \mathrm{m}$, fine, web-like \\
\hline illustrations & $\begin{array}{l}\text { Dissing 1983: fig. 1; } \\
\text { Kristiansen 1985: fig. } 23\end{array}$ & $\begin{array}{l}\text { Moravec 1985: figs. } 6,7 \\
\text { (S. reguisii) }\end{array}$ \\
\hline $\begin{array}{l}\text { Relation } \\
\text { spore ornament/ } \\
\text { cells of hypothecium }\end{array}$ & $\begin{array}{l}\text { large/ } \\
\text { small }\end{array}$ & $\begin{array}{l}\text { fine/ } \\
\text { relatively large }\end{array}$ \\
\hline
\end{tabular}


to such an extent that they may indeed be seen as co-occurring, but distinct species. It is stressed once again that identification in the field should be done with great care.

Acknowledgements. I wish to extend my thanks to Dr. Joop van Brummelen (Leiden) for checking identification of $A$. bicucullata and literature search, Dr. Huub van der Aa (Baarn) for literature search, Mr. Giel Gatzen (Venlo) for donating material of and providing data on A. bicucullata, Mr. John Jagt (Venlo) for translation of the manuscript into English, Mr. Arnoud van Gemert (St. Anthonis) for operating the word-processor, and last but not least my wife Tjân for her continuous support.

\section{References}

Berkeley, M. J. \& Broome, C. E. 1871: Notices of British fungi. - Ann. Mag. Nat. Hist., ser. 4, 7: 425-436.

Billekens, P. 1990: Nieuwe bekerzwammen voor Nederland II: Aleuria bicucullata, Cheilymenia aurea en Cheilymenia raripila. - Natuurhist. Maandbl. 79: 221-228.

Boudier, E. 1881: Nouvelles espèces de champignons de France. - Bull. Soc. Bot. France 28: 91-98.

Boudier, E. 1905-1910: Icones mycologicae. - Paris (reprint 1981). Editions Piantanida, Lausanne. Part II, plates 317, 318, 335; Part IV, text, pp. 176, 177.

Brummelen, J. van 1981: The operculate ascus and allied forms. In: Reynolds, D. R. (ed.), Ascomycete Systematics: 27-48. - Springler-Verlag, New York.

Cooke, M.C. 1875-1879: Mycographia, seu icones fungorum. I. Discomycetes. Part 1. - London.

Dennis, R.W. G. 1978: British Ascomycetes. - 455 pp. J. Cramer, Vaduz.

Dissing, H. 1983: Tre nye baegersvampe (Pezizales) i Danmark. - Svampe 7: 43-45.

Eckblad, F.E. 1968: The genera of the operculate discomycetes. - Nytt Mag. Bot. 15: 1-191.

Gal, M. le 1947: Recherches sur les ornamentations sporales des discomycètes operculés. - Ann. Sci. Nat. Bot., ser 11, 8: 73-297.

Gillet, C.C. 1886: Champignons de France. Les Discomycètes. - 230 pp. Alençon.

Grélet, L.- J. 1938: Les discomycètes de France d'après la classification de Boudier. (Septième fascicule). Bull. Soc. Bot. Centre Ouest 3 (no. spec.): 72-74.
Heim, R. 1962: Quelques ascomycètes remarquables. IV. - Le Pseudotis unicolor (Gill.) nom. nov. et ses sosies. - Bull. Soc. Mycol. France 77: 299-315.

Kornerup, A. \& Wanscher, J.H. 1978: Methuen handbook of colour. Ed. 3. - Eyre Methuen, London.

Kristiansen, R. 1985: Sjeldne og interessante discomyceter (Pezizales) fra Syd-Norge. - Agarica 6: 387-453.

Merkus, E. 1973: Ultrastructure of the ascospore wall in Pezizales. (Ascomycetes) - I. Ascodesmis microscopica (Crouan) Seaver and A. nigricans van Tiegh. - Persoonia 7: 351-366.

Merkus, E. 1974: Ultrastructure of the ascospore wall in Pezizales. (Ascomycetes) - II. Pyronemataceae sensu Eckblad. - Persoonia 8: 1-22.

Merkus, E. 1975: Ultrastructure of the ascospore wall sin Pezizales. (Ascomycetes) - III. Otideaceae and Pezizaceae. - Persoonia 9: 227-247.

Merkus, E. 1976: Ultrastructure of the ascospore wall in Pezizales. (Ascomycetes) - IV. Morchellaceae, Helvellaceae, Rhizinaceae, Thelebolaceae and Sarcoscyphaceae; general discussion. - Persoonia 10: $1-38$.

Moravec, J. 1985: Taxonomic revision within the genus Sowerbyella. - Mycol. Helvet. 1: 427-442.

Moravec, J. 1986: A new species and two new combinations in the genus Sowerbyella. - Mycol. Helvet. 2: 98 .

Moser, M. 1963: Ascomyceten. In: Gams, H. (ed.), Kleine Kryptogamenflora 2a. - 147 pp. Fischer, Stuttgart.

Nannfeldt, J. A. 1938: Contributions to the mycoflora of Sweden. 5. On Peziza catinus Holmskj. ex. Fr. and P. radiculata Sow. ex. Fr. with a discussion on the genera Pustularia Fuck. emend. Boud. and Sowerbyella Nannf. n. gen. - Svensk Bot. Tidskr. 32: $108-120$.

Patouillard, N.T. 1885: Tabulae analyticae fungorum 4: 137-180. - Klincksieck, Paris.

Quélet, M.L. 1886: Enchiridion fungorum. - 352 pp. Doin, Paris.

Seaver, F.J. 1928: The North American Cup-Fungi (Operculates) - Hafner, New York.

Seaver, F.J. 1942: The North American Cup-Fungi (Operculates). Supplement. - Hafner, New York.

Verkley, G.J. M. 1992: Ultrastructure of the apical apparatus of asci in Ombrophila violacea, Neobulgaria pura and Bulgaria inquinans (Leotiales). Persoonia 15: 3-23.

Received on 7 June 1994 